\title{
Optimization of cocoa nib roasting based on sensory properties and colour using response surface methodology
}

\author{
Penentuan kondisi optimum penyangraian \\ keping biji kakao berdasarkan sifat organoleptik dan warna \\ menggunakan response surface methodology
}

D.M.H. Farah ${ }^{1 *)}$, Zaibunnisa, A.H. ${ }^{1)}$, and Misnawi ${ }^{2)}$

\begin{abstract}
Summary
Roasting of cocoa beans is a critical stage for development of its desirable flavour, aroma and colour. Prior to roasting, cocoa bean may taste astringent, bitter, acidy, musty, unclean, nutty or even chocolate-like, depends on the bean sources and their preparations. After roasting, the bean possesses a typical intense cocoa flavour. The Maillard or non-enzymatic browning reactions is a very important process for the development of cocoa flavor, which occurs primarily during the roasting process and it has generally been agreed that the main flavor components, pyrazines formation is associated within this reaction involving amino acids and reducing sugars. The effect of cocoa nib roasting conditions on sensory properties and colour of cocoa beans were investigated in this study. Roasting conditions in terms of temperature ranged from 110 to $160^{\circ} \mathrm{C}$ and time ranged from 15 to 40 min were optimized by using Response Surface Methodology based on the cocoa sensory characteristics including chocolate aroma, acidity, astringency, burnt taste and overall acceptability. The analyses used 9- point hedonic scale with twelve trained panelist. The changes in colour due to the roasting condition were also monitored using chromameter. Result of this study showed that sensory quality of cocoa liquor increased with the increase in roasting time and temperature up to $160^{\circ} \mathrm{C}$ and up to $40 \mathrm{~min}$, respectively. Based on the Response Surface Methodology, the optimised operating condition for the roaster was at temperature of $127^{\circ} \mathrm{C}$ and time of $25 \mathrm{~min}$. The proposed roasting conditions were able to produce superior quality cocoa beans that will be very useful for cocoa manufactures.
\end{abstract}

Key words : Cocoa, cocoa liquor, flavour, aroma, colour, sensory characteristic, response surface methodology.

\section{Ringkasan}

Penyangraian merupakan tahapan yang sangat penting di dalam pengolahan kakao. Cita rasa, aroma dan warna khas cokelat yang baik berkembang selama proses penyangraian. Sebelum disangrai, biji kakao memiliki rasa sepat, pahit, asam, apek, kotor, terasa seperti kacang atau bahkan menyerupai cokelat, tergantung

Naskah diterima (received) 16 Januari 2012 disetujui (accepted) 22 Februari 2012.

1) Faculty of Applied Sciences, Universiti Teknologi MARA 40450 Shah Alam, Selangor, Malaysia.

2) Pusat Penelitian Kopi dan Kakao Indonesia, Jl. PB. Sudirman No. 90, Jember, Indonesia.

*) Alamat penulis (Corresponding Author): nisha@salam.uitm.edu.my. 
kepada sumber biji dan cara pengolahannya. Setelah mengalami penyangraian, biji kakao memiliki cita rasa khas cokelat yang kuat. Reaksi Maillard yang berlangsung selama penyangraian memiliki peran yang penting dalam penbentukan senyawa cita rasa khas cokelat, diantaranya pirazin sebagai senyawa utama cita rasa khas cokelat dari sejumlah asam amino dan gula pereduksi. Penelitian ini mengkaji pengaruh kondisi penyangraian keping biji kakao terhadap sifat sensori dan warna pasta cokelat yang dihasilkan. Kondisi penyangraian yang dikaji meliputi suhu dari 110 sampai $160^{\circ} \mathrm{C}$ dan lama sangrai dari 15 sampai 40 menit. Pengamatan terhadap pasta cokelat yang dihasilkan meliputi aroma cokelat, keasaman, rasa sepat, rasa terbakar dan kesukaan keseluruhan yang dikaji menggunakan 9-titik skala hedonik oleh dua belas panel yang terlatih. Perubahan warna pasta diamati mengunakan chromameter. Hasil penelitian menunjukkan bahwa mutu sensori pasta cokelat meningkat dengan meningkatnya suhu penyangraian sampai $127^{\circ} \mathrm{C}$ dan lama sangrai sampai 25 menit. Berdasarkan Response Surface Methodology diperoleh kondisi optimum penyangraian pada suhu $127^{\circ} \mathrm{C}$ selama 25 menit. Kondisi penyangraian tersebut memungkinkan untuk menghasikan mutu pasta cokelat yang baik dan berguna untuk diterapkan oleh pabrikan cokelat.

Kata kunci: Kakao, pasta kakao, cita rasa, aroma, warna, sifat sensori, response surface methodology.

\section{INTRODUCTION}

The characteristics of aroma, flavour and colour that develop during roasting as a result of Maillard reaction are the most important characteristics in cocoa products. Therefore, these characteristics can be used to determine cocoa beans quality (Misnawi et al., 2004). Upon roasting, cocoa moisture is removed, desired flavors are developed and astringency is reduced; the nib becomes more brittle and generally darkens in color (Minifie, 1990). After roasting the bean posseses the typical intense aroma of cocoa, although remaining tasteless (Jackson, 1990).

Heat must be applied over a sufficient period to allow steady penetration in order to prevent the burning of the cell. Usually a long time-low temperature or short time-high temperature process with temperature up to $150^{\circ} \mathrm{C}$ and roasting time up to $40 \mathrm{~min}$ are used (Holm, 1991). Variety of bean influences roasting conditions; as an illustration, Ghanaian bean may require the heat of $148-184^{\circ} \mathrm{C}$ while Caracas and Maracaibos beans need temperature of $131-146^{\circ} \mathrm{C}$ (Meursing, 1983).

During roasting, pleasant sensory characteristics such as flowery, green, roasty, malty, caramel and nutty will be developed. According to Jinap et al. (1998), temperature is a main factor that affect the colour of roasted cocoa beans. Oxidation and polymerisaton of polyphenols, degradation of protein, and Maillard reaction contribute to brown colour of roasted cocoa beans. Thus, it is necessary to control the roasting time and temperature to develop these desired flavour, aroma and colour without burning the beans. Generally, conventional cocoa roasting methods use temperature in the range of $110-140^{\circ} \mathrm{C}$ and time in the range of 20-50 min (Krysiak, 2006).

Response Surface Methodology (RSM) is an effective tool for optimixing the process when a few factors affect the design responses in certain process. It will give statistical model which help in 
understanding the interaction among the parameters that have been optimized (Nurdiyana \& Mazlina, 2009). Several researchers had investigated the effect of cocoa beans roasting on sensory properties and colour (Counet et al., 2005; Swiechowski, 1996; Ramli, 2008) but there are no studies have been done to optimise roasting process based on sensory quality and colour. Therefore, this study was conducted to determine the optimum roasting conditions using Response Surface Methodology based on these characteristics. The optimised conditions will be very useful for cocoa beans manufactures.

\section{MATERIALS AND METHODS}

\section{Sample Preparation}

Indonesian cocoa beans were obtained from a plantation in Banyuwangi, East Java, Indonesia. Cocoa beans were de-shelled and cut to particle size of $10-5 \mathrm{~mm}$. The desired cocoa beans nib were collected using a sieve. The samples were kept sealed in plastic and store at room temperature for further works.

\section{Roasting Conditions}

Cocoa nib roasting condition had been carried out as suggested by Central Composite Design (CCD) using Design-Expert Software Version 6.0 (Stat Ease Software). Two independent variable were used, temperature $\left(110-160^{\circ} \mathrm{C}\right)$ and time (15-40 min). Eight dependent variable (responses) were determined; sensory characteristics (chocolate aroma, acidity, astringency, burnt taste, overall acceptability) and color $\left(\mathrm{L}, \mathrm{a}^{*}\right.$, and $\left.\mathrm{b}^{*}\right)$. The models with statistically significant parameters $(\mathrm{P} \leq 0.05)$ have been considered and the non-significant parameters $(\mathrm{P} \geq 0.05)$ were withdrawn from the model (Jinap et al., 1995). Cocoa beans were roasted using roaster (Mitsubishi Probat - Magnetic Contractor model SN20, the Pascall Engineering Co. Ltd., England).

\section{Sensory Evaluation}

Sensory evaluation was carried out by using 12 trained panelists. Cocoa liquor was prepared using Mortar and Pestle Mill (Model 2, The Pascall Engineering Co. Ltd., England). Cocoa liquor flavour is classified as strong, moderate and weak. The panelist were required to taste the samples in term of flavour using the scale of 1-9; 0 for not detected, 1-2 for weak, 3-4 for moderately weak, 5-6 for moderately strong, 7-8 for strong, 9-10 for very strong.

\section{Colour Analysis}

Colour of roasted cocoa beans was determined by using Konica Minolta's Chromameter CR-400. The results were expressed in L for luminosity (lightness), $\mathrm{a} *$ (green to red) and $\mathrm{b}^{*}$ (yellow to blue). The determination was replicated three times.

\section{RESULTS AND DISCUSSION}

Preliminary studies had been conducted at different temperature and time in order to get suitable roasting conditions. Based on the CCD, 14 treatments were assigned. Table 1 shows the $\mathrm{CCD}$ for the roasted cocoa beans.

The summary of the results obtain from the effect of independent variable; temperature and time on each independent from CCD are shown in Table 2. The effect of independent variable; temperature (T) and time (min) on each variable was divided into 
first-order (linear), second-order (quadratic) and interactive effects (interaction between pairs of variables). By using lackof-fit and coefficient of determination $\left(\mathrm{R}^{2}\right)$, adequacy of the model can be determined. The significance of equation parameter for all response variables were also assessed by F-ratio at a probability (p) of 0.05 . Zaibunnisa et al. (2009) suggested $\mathrm{R}^{2}$ should be at least 0.80 to have good fit of the model. The close the value of $\mathrm{R}^{2}$ to unity, the better empirical model fits the actual data. The low $\mathrm{R}^{2}$ value observed for colour, $\mathrm{a}^{*}(0.459)$ and $\mathrm{b}^{*}(0.463)$ as shown in Table 2 indicates that $a^{*}$ and $b^{*}$ in cocoa beans was not influenced by the roasting temperature and time as suggested by RSM. All sensory characteristics have significant quadratic model and not sig- nificant lack of fit except for astringency. However, for colour only L value has significant quadratic model and not significant lack of fit.

Polynomial regression equations relating the responses to the independent variable were generated to obtain the optimal level of two factors (A and B). Numerical optimisation was also been carried out to determine the exact optimum level of independent variable leading to desirable roasting condition. Targets were set at maximum for sensory properties and in range for L. By using predicted equations determined by RSM, the optimal condition that depended on independent variable was obtained. Since the astringency, $a^{*}$ and $b^{*}$ were not good indica-

Table 1. Results of Central Composite Design (CCD) for sensory characteristics and colour of roasted cocoa beans Tabel 1. Hasil Rancangan Komposit Sentral untuk karakter sensori dan warna biji kakao sangrai

\begin{tabular}{|c|c|c|c|c|c|c|c|c|c|c|}
\hline \multirow{4}{*}{$\begin{array}{l}\text { Exp. } \\
\text { No. } \\
\text { No. } \\
\text { Perc. }\end{array}$} & \multirow{4}{*}{$\begin{array}{l}\text { Temp. } \\
\text { Suhu } \\
\left({ }^{\circ} \mathrm{C}\right)\end{array}$} & \multirow{4}{*}{$\begin{array}{l}\text { Time } \\
\text { Lama } \\
\text { (min.) }\end{array}$} & \multirow{2}{*}{\multicolumn{5}{|c|}{$\begin{array}{l}\text { Sensory Properties } \\
\text { Sifat sensori }\end{array}$}} & \multirow{3}{*}{\multicolumn{3}{|c|}{$\begin{array}{l}\text { Colour } \\
\text { Warna }\end{array}$}} \\
\hline & & & & & & & & & & \\
\hline & & & \multirow{2}{*}{$\begin{array}{c}\text { Chocolate } \\
\text { aroma } \\
\text { Aroma } \\
\text { cokelat }\end{array}$} & \multirow{2}{*}{$\begin{array}{l}\text { Acidity } \\
\text { Keasaman }\end{array}$} & \multirow{2}{*}{$\begin{array}{l}\text { Astringency } \\
\text { Rasa sepat }\end{array}$} & \multirow{2}{*}{$\begin{array}{l}\text { Burnt taste } \\
\text { Rasa } \\
\text { terbakar }\end{array}$} & \multirow{2}{*}{$\begin{array}{c}\text { Overall } \\
\text { acceptability } \\
\text { Penerimaan } \\
\text { keseluruhan }\end{array}$} & & & \\
\hline & & & & & & & & $\mathrm{L}$ & $a^{*}$ & $b^{*}$ \\
\hline 1 & 135 & 28 & 5.0 & 1.7 & 2.7 & 2.0 & 3.7 & 39.9 & 3.6 & 3.7 \\
\hline 2 & 135 & 28 & 4.9 & 3.0 & 2.6 & 2.7 & 5.1 & 40.3 & 2.4 & 2.4 \\
\hline 3 & 135 & 28 & 5.6 & 4.3 & 2.6 & 1.3 & 6.1 & 39.5 & 2.6 & 3.4 \\
\hline 4 & 135 & 28 & 5.6 & 3.4 & 2.5 & 2.0 & 5.0 & 39.0 & 4.0 & 2.7 \\
\hline 5 & 135 & 28 & 5.2 & 3.7 & 2.8 & 1.6 & 5.4 & 40.9 & 2.8 & 2.7 \\
\hline 6 & 135 & 28 & 5.4 & 4.0 & 2.9 & 2.1 & 4.4 & 40.3 & 1.0 & 1.5 \\
\hline 7 & 110 & 28 & 7.2 & 5.3 & 3.9 & 0.0 & 6.5 & 42.3 & 2.6 & 2.7 \\
\hline 8 & 160 & 28 & 3.0 & 2.4 & 5.6 & 7.0 & 2.6 & 35.3 & 0.7 & 1.0 \\
\hline 9 & 135 & 40 & 2.1 & 2.6 & 4.9 & 6.1 & 2.3 & 36.9 & 2.8 & 3.3 \\
\hline 10 & 135 & 15 & 8.0 & 4.9 & 1.9 & 0.0 & 6.6 & 41.9 & 4.2 & 3.5 \\
\hline 11 & 118 & 36 & 4.6 & 5.3 & 5.3 & 2.1 & 6.4 & 42.8 & 2.5 & 2.3 \\
\hline 12 & 153 & 19 & 4.3 & 3.9 & 6.3 & 2.6 & 5.4 & 36.0 & 3.1 & 3.3 \\
\hline 13 & 153 & 36 & 1.3 & 0.7 & 7.0 & 8.6 & 0.3 & 34.2 & 1.7 & 1.9 \\
\hline 14 & 118 & 18 & 7.0 & 5.3 & 4.4 & 0.7 & 6.0 & 43.9 & 1.4 & 1.7 \\
\hline
\end{tabular}

Note (catatan): sensory properties; $0=$ not detected, $1-2=$ weak, $3-4=$ moderately weak, $5-6=$ moderately strong, $7-8=$ strong, 9-10= very strong (Skala sensori; $0=$ tidak terdeteksi, 1-2=lemah, 3-4= agak lemah, 5-6= agak kuat, 7-8= kuat, 9-10= sangat kuat). 
tors, the major sensory attributes (chocolate Aroma, acidity, burnt taste, overall acceptability) and colour, L (luminosity) were used for optimization.
Cocoa flavour consists of aroma comprises of volatile compounds produced through Maillard reaction and taste, a balance of bitterness, sourness (acidity) and

Table 2. Analyses of variance for response surface for sensory characteristics and colour of roasted cocoa beans Tabel 2. Analisis varian dari respon permukaan karakteristik sensori dan warna biji kakao sangrai

\begin{tabular}{|c|c|c|c|c|c|}
\hline $\begin{array}{l}\text { Parameters } \\
\text { Tolok ukur }\end{array}$ & $\begin{array}{l}\text { Model } \\
\text { Model }\end{array}$ & $\begin{array}{l}\text { Lack of fit } \\
\text { Ketidak- } \\
\text { sesuaian }\end{array}$ & $\begin{array}{l}\mathrm{R}^{2} \\
R^{2}\end{array}$ & $\begin{array}{l}\text { Equation } \\
\text { Persamaan }\end{array}$ & $\begin{array}{l}\text { Significant } \\
\text { model term } \\
\text { Bagian model } \\
\text { yang nyata }\end{array}$ \\
\hline Chocolate aroma & Quadratic & Not & 0.962 & $\mathrm{Y}=5.28-1.15 \mathrm{~A}-1.71 \mathrm{~B}-0.29 \mathrm{~A}^{2}$ & $\mathrm{~A}, \mathrm{~B}$ \\
\hline Aroma cokelat & $\begin{array}{l}\text { Significant } \\
\text { Nyata } \\
\text { kudratik }\end{array}$ & $\begin{array}{l}\text { Significant } \\
\text { Tidak nyata }\end{array}$ & & $-0.31 \mathrm{~B}^{2}-0.16 \mathrm{AB}$ & \\
\hline $\begin{array}{l}\text { Acidity } \\
\text { Keasaman }\end{array}$ & $\begin{array}{l}\text { Quadratic } \\
\text { significant } \\
\text { Nyata } \\
\text { kudratik }\end{array}$ & $\begin{array}{l}\text { Not } \\
\text { significant } \\
\text { Tidak nyata }\end{array}$ & 0.826 & $\begin{aligned} \mathrm{Y}= & 3.35-1.26 \mathrm{~A}-0.08 \mathrm{~B}+0.26 \mathrm{~A}^{2} \\
& +0.18 \mathrm{~B}^{2}-0.79 \mathrm{AB}\end{aligned}$ & $\mathrm{A}, \mathrm{B}, \mathrm{AB}$ \\
\hline $\begin{array}{l}\text { Astringency } \\
\text { Rasa sepat }\end{array}$ & $\begin{array}{l}\text { Quadratic } \\
\text { significant } \\
\text { Nyata } \\
\text { kudratik }\end{array}$ & $\begin{array}{l}\text { Significant } \\
\text { Nyata }\end{array}$ & 0.877 & $\begin{aligned} \mathrm{Y}= & 2.66+0.74 \mathrm{~A}+0.73 \mathrm{~B}+1.45 \mathrm{~A}^{2} \\
& +0.77 \mathrm{~B}^{2}-0.027 \mathrm{AB}\end{aligned}$ & $\mathrm{A}, \mathrm{B}, \mathrm{A} 2, \mathrm{~B} 2$ \\
\hline $\begin{array}{l}\text { Burnt Taste } \\
\text { Rasa terbakar }\end{array}$ & $\begin{array}{l}\text { Quadratic } \\
\text { significant } \\
\text { Nyata } \\
\text { kudratik }\end{array}$ & $\begin{array}{l}\text { Not } \\
\text { significant } \\
\text { Tidak nyata }\end{array}$ & 0.822 & $\begin{aligned} \mathrm{Y}= & 2.45+2.27 \mathrm{~A}+2.01 \mathrm{~B}+0.58 \mathrm{~A}^{2} \\
& +0.36 \mathrm{~B}^{2}+1.14 \mathrm{AB}\end{aligned}$ & $\mathrm{A}, \mathrm{B}$ \\
\hline $\begin{array}{l}\text { Overall } \\
\text { Acceptability } \\
\text { Penerimaan } \\
\text { keseluruhan }\end{array}$ & $\begin{array}{l}\text { Quadratic } \\
\text { significant } \\
\text { Nyata } \\
\text { kudratik }\end{array}$ & $\begin{array}{l}\text { Not } \\
\text { significant } \\
\text { Tidak nyata }\end{array}$ & 0.915 & $\begin{aligned} \mathrm{Y}= & 4.96-1.52 \mathrm{~A}-1.35 \mathrm{~B}-0.21 \mathrm{~A}^{2} \\
& -0.26 \mathrm{~B}^{2}-1.37 \mathrm{AB}\end{aligned}$ & $\mathrm{A}, \mathrm{B}, \mathrm{AB}$ \\
\hline $\mathrm{L}$ & $\begin{array}{l}\text { Quadratic } \\
\text { significant } \\
\text { Nyata } \\
\text { kudratik }\end{array}$ & $\begin{array}{l}\text { Not } \\
\text { significant } \\
\text { Tidak nyata }\end{array}$ & 0.912 & $\begin{aligned} \mathrm{Y}= & 39.97-3.32 \mathrm{~A}-1.24 \mathrm{~B}-0.55 \mathrm{~A}^{2} \\
& -0.24 \mathrm{~B}^{2}-0.16 \mathrm{AB}\end{aligned}$ & $\mathrm{A}, \mathrm{B}$ \\
\hline$a^{*}$ & $\begin{array}{l}\text { Quadratic } \\
\text { not significant } \\
\text { Tidak nyata } \\
\text { kudratik }\end{array}$ & $\begin{array}{l}\text { Not } \\
\text { significant } \\
\text { Tidak nyata }\end{array}$ & 0.459 & $\begin{aligned} \mathrm{Y}= & 2.71-0.22 \mathrm{~A}-0.27 \mathrm{~B}-0.63 \mathrm{~A}^{2} \\
& +0.29 \mathrm{~B}^{2}-0.63 \mathrm{AB}\end{aligned}$ & - \\
\hline$b^{*}$ & $\begin{array}{l}\text { Quadratic } \\
\text { not significant } \\
\text { Tidak nyata } \\
\text { kudratik }\end{array}$ & $\begin{array}{l}\text { Not } \\
\text { Significant } \\
\text { Tidak nyata } \\
\text { nyata }\end{array}$ & 0.463 & $\begin{aligned} \mathrm{Y}= & 2.74-0.15 \mathrm{~A}-0.14 \mathrm{~B}-0.54 \mathrm{~A}^{2} \\
& +0.25 \mathrm{~B}^{2}-0.51 \mathrm{AB}\end{aligned}$ & - \\
\hline
\end{tabular}

Note (Catatan): The central composite design was generated using Design Expert 6.0 Software (Rancangan Sentral Komposit mengunakan perangkat lunak Design Expert 6.0) $\mathrm{A}=$ Temperature, ${ }^{\circ} \mathrm{C}\left(\right.$ suhu, $\left.{ }^{\circ} \mathrm{C}\right) ; \mathrm{B}=$ Static time, min (waktu tetap, menit).

PElita PERKEbUnAN, Volume 28, Nomor 1, Edisi April 2012 


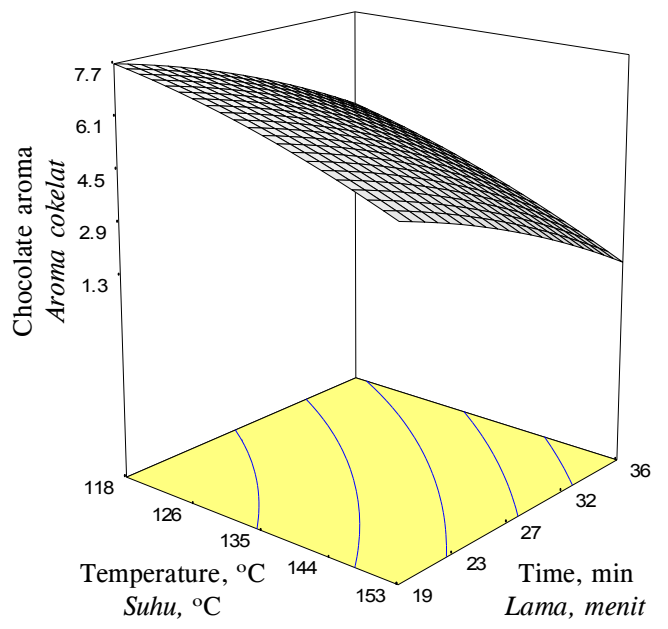

(A)

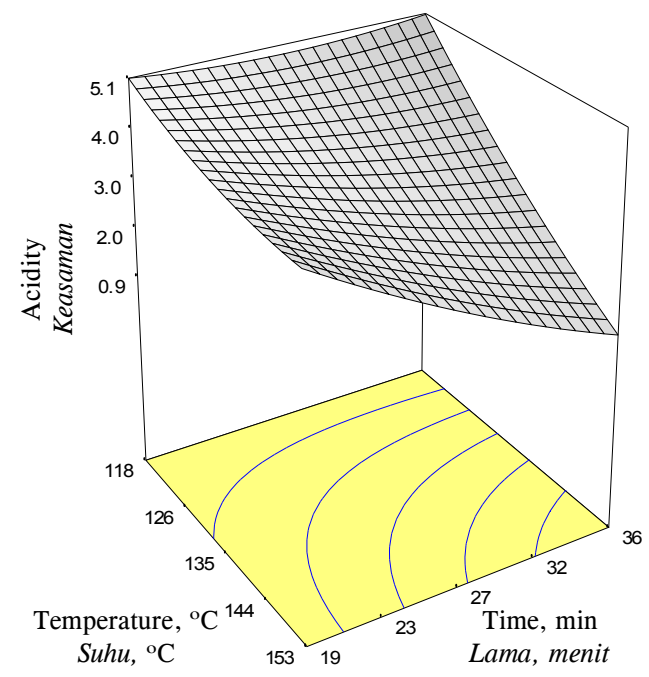

(B)

Figure 1. Design-Expert 3D plots for chocolate aroma (A) and acidity (B).

Gambar 1. Plot Design-Expert 3D untuk aroma cokelat (A) dan keasaman (B).

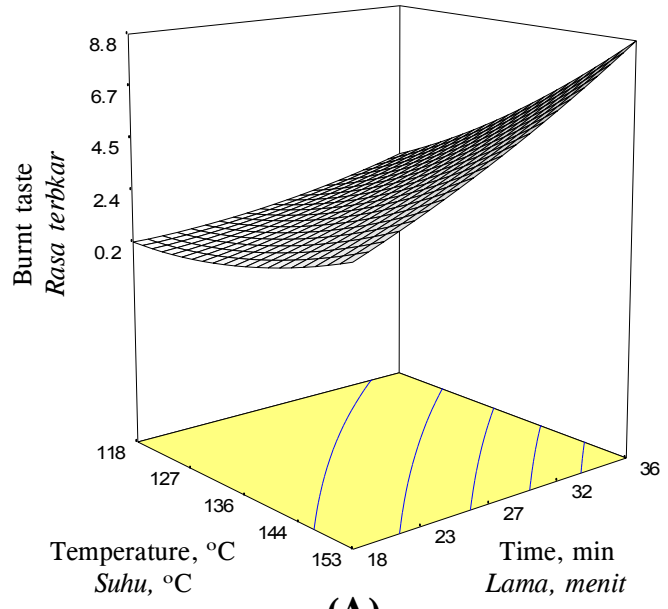

(A)

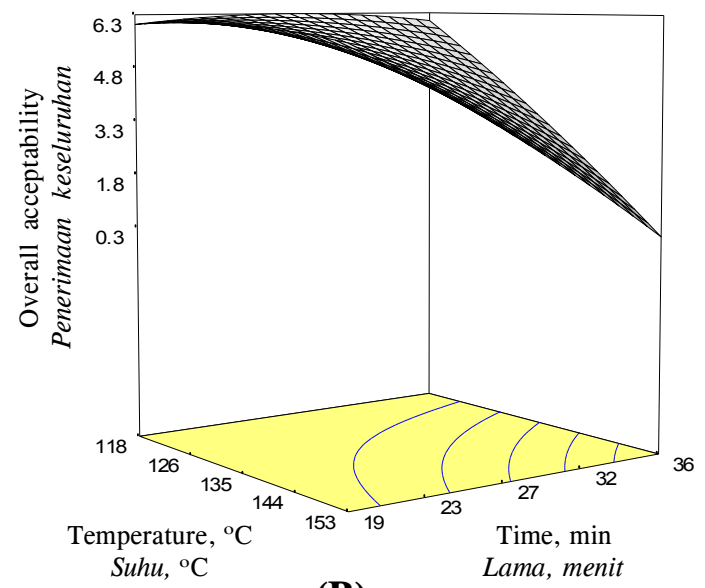

(B)

Figure 2. Design-Expert 3D plots for burnt taste (A) and overall acceptability (B).

Gambar 2. Plot Design-Expert 3D untuk rasa terbakar (A) dan penerimaan keseluruhan (B).

sweetness sensation in mouth (Misnawi \& Wahyudi, 2010). Chocolate aroma is very specific and cannot be replaced by other sources. As shown in Figure 1A, the highest chocolate aroma was obtained at high roasting temperature $\left(135^{\circ} \mathrm{C}\right)$ but at short roasting time (15 $\mathrm{min})$. This is most likely due to cocoa flavour that will be develop better at high temperature, but it will burnt if roasting temperature is too high. This burnt flavour will mask the cocoa flavour. This result correlates well with burnt taste results, whereby it increased with roasting time and temperature, Figure 2A. Du-

PELITA PERKEbUNAN, Volume 28 Nomor 1, Edisi April 2012 
ring roasting, diketopiperazines or know as cyclic dipeptides will be generate and mix with theobromine. This will induce the bitter taste in cocoa (Beckwett \& Ziegleder, 2009). As temperature increase, more formation of diketopiperazines will generate and this will result to burnt taste in cocoa.

Inverse relationship was noticed for acidity as shown in Figure 1B. Acidity was an important attribute to balance cocoa flavour. However, excessive acidity will give defect flavour for cocoa beans (Ramli et al., 2008). In this study, $\mathrm{pH}$ obtained for cocoa beans was 5.0-5.1 and after roasting was 5.1-5.3. This acidity usually preferred by chocolate manufacture (Beckwett $\&$ Ziegleder, 2009). In term of overall acceptability, there were gradual acceptability of the panelists as time and temperature increased up to a certain level and started to reduce after that as shown in Figure 2B.

Besides sensory characteristics, colour of roasted beans and the loss of weight occurred after roasting also can be used as reference standard to characterize the best of roasting condition as suggested by Luciane (Luciane et al., 2001). Thus, in this study colour value L (luminosity) was used to determine the quality of the beans. The $\mathrm{L}$ value was decreased linearly with increase in temperature and time as shown in Figure 3. This result correlates well with the findings obtained by Luciane (Luciane et al., 2001). Similar results were obtained by Krysiak (2006) whereby superior colour pigment content in roasted cocoa beans can be obtained after roasting for $120-140^{\circ} \mathrm{C}$ for $20 \mathrm{~min}$. The colour component $\mathrm{L}$, found in optimal roasting condition $\left(127^{\circ} \mathrm{C}\right.$ at $\left.25 \mathrm{~min}\right)$ was 39.97 .

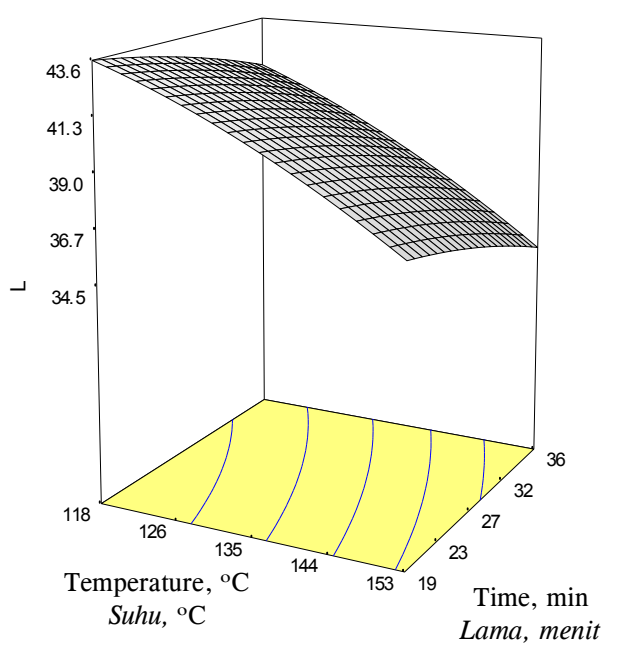

Figure 3. Design-Expert 3D plot for colour value, L (luminosity).

Gambar 3. Plot Design-Expert untuk nilai warna $L$ (luminosity).

Statistical optimisation based on maximum sensory attributes (chocolate aroma, acidity, spoilage, overall acceptability) and colour, L (luminosity) was a temperature $128^{\circ} \mathrm{C}$ and a time of $25 \mathrm{~min}$ which gave desirability value of 0.715 . This optimized condition can be produce superior quality cocoa beans that will be very useful for cocoa manufacturers.

\section{CONCLUSION}

From this study, sensory quality of cocoa beans increased with the increase in roasting time and temperature from 110 to $160^{\circ} \mathrm{C}$ and 15 to $40 \mathrm{~min}$, respectively. The optimized condition in terms of time and temperature for cocoa beans roasting is at temperature of $127^{\circ} \mathrm{C}$ and a time of $25 \mathrm{~min}$. 


\section{ACKNOWLEDGEMENTS}

The authors are grateful to Universiti Teknologi MARA (UiTM) for generous financial support (Excellent fund - 600RMI/ST/DANA 5/3/Dst (225/2011)) and Indonesian Coffee and Cocoa Research Institute (ICCRI) for useful discussion and advise and for using the laboratory.

\section{REFFERENCES}

Beckwett, S.T. \& G. Ziegleder (2009). Industrial Chocolate Manufacture and Use $4^{\text {th }}$ edition. Backwell Publishing, United Kingdom.

Counet, C.; C. Ouwerx; D. Rosoux \& S. Collin (2004). Relationship between procyanidin and flavour content of cocoa liquor from different origin. Journal of Agricultural and Food Chemistry, 52, 6243-6249.

Holm, C.S. (1991). Pyrazines and Organic Acids in Cocoa: Their Analysis and Effect on Chocolate Flavour, M.Sc. Thesis. Quensland: Quensland University of Technology Brisbane.

Jackson, E.B. (1990). Sugar, Confectionary Manufacturer. New York: Van Nostrand Reinhold.

Jinap S.; P.S. Dimick \& R. Hollender (1995). Flavour evaluation of chocolate formulated from cocoa beans from different countries. Journal of Food Control, 6, 105-110.

Jinap, S.; W.L. Wan-Rosli; A.R. Russly \& L.M. Nurdin (1998). Effect of roasting time and temperature on volatile components profile during nib roasting of cocoa bean (Theobroma cocoa). Journal of the Science and Food Agriculture, 77, 441-448.

Krysiak, W. (2006). Influence of roasting conditions on coloration of roasted cocoa beans. Journal of Food Engineering, 77, 449-453.
Luciane, C.M.; H.C.De. Menezes; M. Aparecida \& A.P.D. Sivia (2001). Optimizination of the roasting of robusta coffee using acceptability test and RSM. Journal of Food Quality and Preference, 12, 153-162.

Meursing, E.H. (1983). Cocoa Powder for Industrial Processing $3^{\text {rd }}$ ed. Cacaofabriek De Zaan B.V.

Minifie, B.W. (1990). Chocolate, Cocoa and Confectionery $2^{\text {nd }}$ ed. Westport, Connecticut: Avi Publishing Co.

Misnawi, J. \& T. Wahyudi (2010). Cocoa Chemistry and Technology (Roles of Polyphenols and enzymes reactivation in flovour development of under-fermented cocoa beans. Lambert Academic Publishing, United Kingdom.

Misnawi, J.; S. Jinap; B. Jamilah \& S. Nazamid (2004). Sensory properties of cocoa liquor as affected by polyphenol concentration and duration of roasting. Journal of Food Quality and Preferences, 15, 403-409.

Nurdiyana, H. \& S.M.K. Mazlina (2009). Optimization of protein extraction from fish waste using response surface methodology. Journal of $A p$ plied Science, 9, 3121-3125.

Ramli, N.; O. Hasssa; M. Said; W. Samsudin \& N.A. Idris (2008). Influence of roasting conditions on volatile flavour of roasted Malaysia cocoa bean (abstract). Journal of Food Processing and Preservation, 30, 280-298.

Swiechowski, Cz. (1996). Chocolate production. Cocoa beans roasting-comparison of methods. Przeglad Piekarskii Cukierniczy, 4, 30-33.

Zaibunnisa, A.H.; S. Norasikin; S. Mamot \& H. Osman (2009). An experimental design approach for the extraction of volatile compounds from turmeric leaves (Curcuma domestica) using Pressurized Liquid Extraction (PLE). Journal of Food Science and Technology, 42, 233-238. 